J. Product. \& Dev., 17(1):79- 103(2012)

\title{
THE INFLUENCE OF STOCKING DENSITY AND DIETARY SILYMARIN LEVEL ON PRODUCTIVE PERFORMANCE AND SOME PHYSIOLOGICAL TRAITS OF INSHAS COCKS LOCAL STRAIN
}

\section{S.M.M. Mousa ${ }^{*}$ and M.S. Shoeib ${ }^{* *}$}

* Poultry Breeding Department, Animal Production. Research. Institute, Agriculture Center, Egypt

** Poultry Nutrition Department, Animal Production. Research. Institute, Agriculture Center, Egypt.

\section{ABSTRACT:}

The present work was conducted to study the effect of various stoking densities and dietary silymarin level in cock's diet to alleviate the negative effects of increasing stocking density on productive performance and physiological stress of Inshas cocks. A $3 \times 3$ factorial design experiment was performed including three stocking densities (10, 12 or $\left.14 \mathrm{birds} / \mathrm{m}^{2}\right)$ with three levels of silymarin $(0,250$ and $500 \mathrm{mg} / \mathrm{kg}$ diet). A total number of 324 male chicks of Inshas local strain at 4 weeks of age were randomly distributed into 9 treatment groups and housed during the experimental period 4-16 weeks of age in wire cages having dimensions of $80 \times 125 \times 55 \mathrm{~cm}$.

Results obtained showed that: There were significant negative effects $(P<0.05)$ on live body weight, live body weight gain, feed consumption (except 4-8 Weeks), carcass, dressing, breast and thigh percentages relative to pre-slaughter by increasing stocking density at the different experimental periods. Mortality rate of chickens housed at 14 bird $/ \mathrm{m}^{2}$ were significantly higher than those of birds housed at 10 bird $/ \mathrm{m}^{2}$. Abdominal fat \%, erythrocytes cells, leucocytes cells, heterophils $(H)$ and $H / L$ ratio were significantly $(P<0.05)$ increased with increasing stocking densities (12 or 14 birds $\left./ \mathrm{m}^{2}\right)$. Tibia weight, tibia length, tibia calcium and tibia phosphorous (\% of ash) were higher significantly $(P \leq 0.05)$ higher for male chicks kept at $10 \mathrm{birds} / \mathrm{m}^{2}$ compared with other densities, followed by male chicks stocked at 12 birds $/ m^{2}$ then male chicks stocked at 14 birds $/ m^{2}$. There were insignificant differences for feed conversion and chemical composition of breast and thigh of cocks with different stocking densities.

Live body weight and weight gain values were almost significantly $(P<0.05)$ improved with silymarin levels compared to the basal diet. Feed conversion in male chicks was significantly $(P<0.05)$ 
improved with dietary silymarin levels during the all experimental periods. Carcass, dressing, breast and thigh percentages relative to preslaughter, crude protein percentage of breast, serum total protein and globulin were almost significantly $(P<0.05)$ increased while, abdominal fat\% and ether extract percentages of breast and thigh, leucocytes cells and lymphocytes $(L)$ serum AST and ALT were significantly $(P<0.05)$ decreased with silymarin supplementation $(500 \mathrm{mg}$ silymarin/Kg diet) as compared with control group.

Body weight at 16 weeks of age and body weight gain during 4-8 and 4-16 weeks of age, feed consumption during 8-16 and 4-16 weeks of age were significantly $(P<0.05)$ influenced by interaction between stocking density and silymarin level. It is noted that mortality rate was lowered with silymarin levels at different stocking densities studied. Tibia measurements, its mineral contents and chemical composition of breast and thigh of cocks was not significantly affected by interaction between stocking density and silymarin level. Increasing stocking density to 12 birds / $\mathrm{m}^{2}$ gave the best net revenue and economical efficiency compared with that of 10 or 14 birds $/ \mathrm{m}^{2}$. The best net revenue and economical efficiency were recorded with cocks fed $250 \mathrm{mg}$ silymarin $\mathrm{kg}$ diet and followed by $500 \mathrm{mg}$ silymarin $/ \mathrm{kg}$ diet as compared with control group.

In conclusion, increasing stocking density to 12 birds $/ \mathrm{m} 2$ with levels 250 or $500 \mathrm{mg}$ silymarin $\mathrm{kg}$ diet improved most productive performance and some physiological traits of Inshas cocks.

Key words: Stocking density, silymarin, productive performance, carcass, blood, economical efficiency.

\section{INTRODUCTION}

The stocking density in chickens vary greatly according to countries , breeding systems and body weight. The use of high-density storage could reduce the individual growth (Turkyilmaz, 2008; Skomorucha et al., 2009). But total meat production per unit surface floor increased and that resulted in higher profits due to economic benefits, so incentive producers may not reduce the stocking densities (Feddes et al., 2002). However, high stocking density has been reported to increase the incidence of diseases, mortality (Shanawany, 1988) and caused stress on the birds compared with the lower stocking ones. Furthermore, high stocking density has been reported to increase ammonia production, footpad lesions, litter moisture, locomotion, heat stress, and preening (Ritz et al., 2005; Bennett et al., 2003). Meanwhile, high stocking densities reduce the fixed costs of production and produce more kilograms of broiler per area. Therefore, up to a critical point, profitability increased 
with increased stocking density (Puron et al., 1995). Effects of group size and density on social behavior and movement within space available has considerable attention (Estevez, 2007; Leone et al., 2010), but few studies investigate their impact on broiler performance under feed additives feeding.

Several methods are available to alleviate the effect of increased stocking density on performance of poultry. In this respect, recently, the global strategy of poultry farming is focused on quality, safety and environmental purity of products. Antibiotics and growth promoters are not used in most countries of European Union (Fisinin and Tardat'yan, 2003; Egorov and Papazyan, 2007). These facts make it necessary to find effective and safe means - natural biologically active compounds.

Natural extractives of plant origin provide a mild stimulating effect on metabolic processes in poultry, which has a positive effect on its productivity, intensifies the immune response and thereby increases viability and preservation of poultry. Another important advantage of plant extractives is their relatively low cost. Silymarin - a flavonolignan complex extracted from milk thistle - is one of most promising plant bioactive substances. High antioxidant activity of silymarin (Wilasrusmee et al 2002; Kurkin 2003) promotes immunity and health in poultry. Silymarin is also important for maintaining quality and safety of feeds by preventing them from rancidity and microbial contamination. Along with that, the pronounced hepatoprotective properties of silymarin make it a promising feed supplement when growing broiler chickens and laying hens need extra protection of the liver owing to high intensity of metabolic processes (Fisinin et al 2011). Therefore, silymarin can be widely used in poultry farming. However, natural silymarin has a very low bioavailability, which limits the expression of its biological activity. A significant increase in bioavailability was achieved by creation of its liposomal nanoform. Numerous experiments (Lutsenko et al., 2008; Arkhapchev et al., 2009) have shown that the liposomal nanoform of silymarin has a much more pronounced therapeutic activity and allows introducing it in lower doses relative to the native Artificial intelligence. In addition, essential phospholipids - components of the liposomal nanoform - can increase productivity and improve antioxidant status of poultry. The purpose of this work was to study the safety of dietary silymarin and its impact on key parameters of poultry.

Therefore, this study aims to increase the stoking density from 10 to 12 or 14 birds $/ \mathrm{m}^{2}$ and to evaluate the effects of increasing silymarin level from 0 to 250 or $500 \mathrm{mg} / \mathrm{Kg}$ diet to alleviate the negative effects of increasing stocking density on productive performance and physiological stress of Inshas cocks. 


\section{MATERIALS AND METHODS}

The experimental work of this study was carried out at Inshas Poultry Research Station, Animal Production Research Institute, Agriculture Research Center, Giza, Egypt, during the period from March to June, 2010.

A $3 \times 3$ factorial design experiment was performed including three stocking densities $\left(10,12\right.$ or $\left.14 \mathrm{birds} / \mathrm{m}^{2}\right)$ using wire cages with dimensions of $80 \times 125 \times 55 \mathrm{~cm}$ and three dietary levels of silymarin $(0,250$ and $500 \mathrm{mg} / \mathrm{Kg}$ diet, Pharma swede Egypt). A total number of 324 male chicks of Inshas local strain at 4 weeks of age were randomly distributed into 9 treatment groups with nearly equal average body weight $(182.26 \pm 1.40)$. Each of $1^{\text {st }}, 2^{\text {nd }}$ and $3^{\text {rd }}$ groups was consisted of 30 birds in three replicates ( 10 cocks/ each) and placed in 10 birds $/ \mathrm{m}^{2}$ to achieve cock density of $1000 \mathrm{~cm}^{2} / \mathrm{bird}$. While, each of $4^{\text {th }}, 5^{\text {th }}$ and $6^{\text {th }}$ groups included 36 birds in three replicates ( 12 cocks/ each) and placed in 12 birds $/ \mathrm{m}^{2}$ to achieve cock density of $833 \mathrm{~cm}^{2} /$ bird. Whereas, each $7^{\text {th }}, 8^{\text {th }}$ and $9^{\text {th }}$ groups included 42 birds in three replicates ( 14 cocks/ each) and placed in 12 birds $/ \mathrm{m}^{2}$ to achieve cock density of $714 \mathrm{~cm}^{2} /$ bird. The first, fourth and seventh groups were fed on the starter diet $(19.11 \% \mathrm{CP})$ from $4-8$ weeks of age and the grower diet $(15.05 \% \mathrm{CP})$ from $8-16$ weeks of age. The second, fifth and eighth groups were fed each of the starter and grower diets supplemented with $250 \mathrm{mg}$ silymarin/Kg diet. While, the third, sixth and ninth groups were fed each of the starter and grower diets supplemented with 500 silymarin/Kg diet. The starter and grower diets were formulated from plant origin.

All cages were equipped with feeding hoppers made of galvanized steel sheets and automatic drinkers with nipples for drinking. The experimental treatment groups were kept under similar management system. Artificial light was provided continuously during night without interruption. The starter and grower diets (Table 1) were formulated to meet the nutrient requirements of chicks according to NRC (1994). Birds in each replicate were weekly weighed and the feed consumed was recorded. Feed conversion (gram feed /gram gain) was calculated for different experimental periods. Mortality was recorded daily and calculated for the entire experimental period.

At the end of the experimental period (16 weeks of age) a slaughter test was performed on 27 birds of nearly similar weight ( 3 birds from each group).

The assigned birds were deprived of feed for 12 hours prior to slaughter, thereafter they were individually weighted, slaughtered by cutting the throat and jugular vein with a sharp knife, after complete bleeding birds were plucked by dry-plucking and their weights were recorded. Shanks and head were separated, the birds were then eviscerated and intestine, gizzard, lungs, spleen, liver, heart and reproductive organs were removed. The carcass, giblets (heart, empty gizzard and liver), abdominal fat, dressing weight (carcass 
Table 1. Composition and calculated analyses of starter and grower experimental diets.

\begin{tabular}{lcc}
\hline $\begin{array}{l}\text { Ingredients } \\
(\%)\end{array}$ & $\begin{array}{c}\text { Starter } \\
\text { diet }\end{array}$ & $\begin{array}{c}\text { Grower } \\
\text { diet }\end{array}$ \\
\hline Yellow corn & 65.00 & 63.50 \\
Soybean meal (44\%). & 30.54 & 16.00 \\
Wheat bran & 0.94 & 16.78 \\
Dicalcium phosphate & 1.51 & 1.60 \\
Limestone & 1.40 & 1.45 \\
Methionione & 0.01 & 0.07 \\
Premix* & 0.30 & 0.30 \\
Na Cl & 0.30 & 0.30 \\
\hline Total & $\mathbf{1 0 0 . 0 0}$ & $\mathbf{1 0 0 . 0 0}$ \\
\hline Calculated analysis (\%) *** & & \\
Crude protein & 19.11 & 15.05 \\
Calcium & 0.97 & 0.99 \\
Available P & 0.42 & 0.40 \\
CF & 3.67 & 4.36 \\
Lysine & 1.00 & 0.70 \\
Methionine +Cystine & 0.64 & 0.60 \\
ME. Kcal /Kg & 2871.13 & 2704.77 \\
\hline VitMin Per
\end{tabular}

*Vit+Min Permix1 was added as 3.0Kg per ton of diet and supplied the following (as mg or IU per Kg of diet): Vit: A :12000 IU, VitD3 :1000 IU, Vit E: 10mg,Vit K3:1mg, Vit B1 :1mg, Vit B2 :4mg, Vit B6:1.5mg, Pantothenic acid: 10mg, Vit B12:0.01mg, Folic acid :1mg, Niacin :20mg, Biotin :0.05mg, Choline chloride: 500mg, Zn: $45 \mathrm{mg}, \mathrm{Cu}$ : $3 \mathrm{mg}$, Fe: 30mg, I: 0.3mg, Se: $0.1 \mathrm{mg}$, Mn :40mg, Ethoxyquin :3000mg.

** Calculated according to NRC (1994).

weight plus giblets weight), as well as, breasts and thighs were weighed and recorded as percentages of pre-slaughter weight. Chemical compositions of breast and thigh sample were determined according to AOAC (1994). The right tibia of each bird was selected as a bone sample. Tibia bones were placed in boiling water for 3 minutes and surrounding meat and connective tissues were subsequently cleaned. After that tibia bones were air dried for 7 days and bone fragments were fat extracted by diethyl ether for 48 hours, and then burned in a Muffle France at a lower temperature degree of $70^{\circ} \mathrm{C}$ for 24 hours to maintain the mineral contents from loss. After that the degree of Muffle France was increased to reach $600{ }^{\circ} \mathrm{C}$ for 3 hours and bone ash contents were weighed and prepared for calcium and phosphorous determination according to AOAC (1994). Calcium and phosphorous levels were determined by atomic absorption spectrometer apparatus (SK1, Power input, A.H. Series).

Blood samples for biochemical determinations were individually taken at the same time of slaughtering from 3 birds of each group. Blood samples were collected into dry clean tubes containing heparin drops to determine hematological parameters including, erythrocytes (RBC's), and leucocytes 
(WBC's) blood cells and its differential as described by Hawkey and Dennett (1989). Another centrifuge tubes with no heparin were used to collect another blood samples, centrifuged for 15 minutes $(4000 \mathrm{rpm})$ and serum was separated and stored in deep freezer at approximately $-20^{\circ} \mathrm{C}$ for further chemical analysis. Serum total protein and albumin were determined according to Witt and Trendelenburg (1982) and Doumas, (1971), respectively. Globulin concentration was calculated as the difference between total protein and albumin. Total cholesterol was determined according to (Watson, 1960). Assay of serum aspartate aminotransferase (AST) and alanine aminotransferase (ALT) activities were conducted according to procedures of Reitman and Frankel (1957).

Data were statistically analyzed using $\mathrm{SAS} \AA$ software computer program (SAS, 2003). The significant differences between means were detected according to Duncan (1955). Mortality percentages were analyzed by using Chi - square test.

\section{RESULTS AND DISCUSSION}

\section{Growth performance taits:}

Results in Table (2) showed that increasing stocking density had significant negative effect $(\mathrm{P}<0.05)$ on live body weight and body weight gain of cocks at different experimental periods. These results are in agreement with those obtained by Al Homidan and Robertson (2007) who indicated that increasing stocking density of Hybro broiler chicken from 10 to $15 \mathrm{bird} / \mathrm{m}^{2}$ was associated with a significant $(\mathrm{P}<0.05)$ decrease in mean body weight of $102 \mathrm{~g}$ at 42 days, mean daily weight gain was reduced by $2.43 \mathrm{~g} / \mathrm{d}$. Sekeroglu et al. (2011) reported that broiler chicks of the highest stocking density group (17 birds $\left.\mathrm{m}^{2}\right)$ had the lowest $(\mathrm{P}<0.01)$ live weight gain among the three stocking density groups tested $\left(9,13\right.$ and 17 birds $\left.\mathrm{m}^{2}\right)$ during the $4^{\text {th }}, 5^{\text {th }}$ and $6^{\text {th }}$ weeks. Zuowei et al. (2011) stated that the high stocking density treatment (16 males or 18 females $/ \mathrm{m}^{2}$ ) significantly decreased body weight gain as compared with the control group ( 10 males or 12 females $\left./ \mathrm{m}^{2}\right)$ at $35 \mathrm{~d}$ of age. On the contrary, dietary silymarin levels almost improved $(\mathrm{P}<0.05)$ live body weight and weight gain of cocks at different experimental periods (Table 2). The superior increased in body weight and body weight gain with silymarin supplementation may be due to the improvements in feed consumption and feed conversion (Table 3). The observed changes can be the result of more active metabolism of nutrients in the body stimulated by silymarin. Results of the present study are in agreement with the findings of Tedesco et al. (2004), who reported that addition of silymarin phytosome in the feed at $600 \mathrm{mg} / \mathrm{Kg}$ of body weight resulted in an increase of $14.83 \%$ in body weight. Similarly, 
Gowda and Sastry (2000) confirmed significant $(\mathrm{P}<0.05)$ improvement of milk thistle (silymarin) on body weight gain and attributed the effect to antioxidant activity that stimulated protein synthesis by bird's enzymatic system. Fisinin et al. (2011) reported that adding of silymarin increasing of average weight gain of broiler chicks by $1.3 \%$.

Body weight at 16 weeks of age and body weight gain during 4-8 and 4-16 weeks of age were significantly $(\mathrm{P}<0.05)$ influenced by interaction between stocking density and dietary silymarin level. It could be noticed that stocking density of 10 birds $/ \mathrm{m}^{2}$ and $500 \mathrm{mg}$ silymarin/Kg diet recorded the best values of body weight at 16 weeks of age and body weigh gain at 4-16 weeks of age.

Averages of feed consumption, feed conversion and mortality rate of male chicks as affected by stocking density and dietary supplementation silymarin and their interactions at different experimental periods are illustrated in Table 3. Feed consumption (except from 4-8 weeks of age) was decreased $(\mathrm{P}<0.01)$ due to increasing stocking density compared to $10 \mathrm{birds} / \mathrm{m}^{2}$ stocking density. While, feed conversion of cocks was not significantly affected by stocking density all the experimental periods. Similar results were reported by Puron et al., (1995) who indicated that there was a linear reduction in feed intake of broiler chickens when stocking density increased from 10 to 20 birds $/ \mathrm{m}^{2}$. Also, Feddes et al., (2002) showed that feed consumption decreased in broiler chickens when stocking density was increased from 14.3 to 23.8 bird $/ \mathrm{m}^{2}$. Tollba et al., (2006) indicated that feed consumption was significantly $(\mathrm{P}<0.01)$ decreased as stocking densities $\left(8,12\right.$ and 16 birds $\left./ \mathrm{m}^{2}\right)$ were increased. Al Homidan and Robertson (2007) showed that increasing stocking density of Hybro broiler chicken from 10 to $15 \mathrm{bird} / \mathrm{m}^{2}$ was associated with a significant $(\mathrm{P}<0.05)$ decrease in feed consumption by $8.5 \mathrm{~g} / \mathrm{d}$. Zuowei et al. (2011) stated that the high stocking density treatment (16 males or 18 females $/ \mathrm{m}^{2}$ ) significantly decreased feed consumption and feed conversion ratio as compared with the control group (10 males or 12 females $/ \mathrm{m} 2$ ) at $35 \mathrm{~d}$ of age.

Feed consumption of cocks was not significantly affected by dietary silymarin supplementation all experimental periods. Whereas, dietary silymarin supplementation significant $(\mathrm{P}<0.05)$ improved feed conversion during all experimental periods (Table 3). The results previous in good are in agreement with the findings of Tedesco et al. (2004) who reported a $22.29 \%$ improvement in feed intake, with silymarin phytosome supplementation at $600 \mathrm{mg} / \mathrm{Kg}$ of body weight. Zahid and Durrani (2007) observed that broilers fed $15 \mathrm{~g}$ milk thistle (silymarin) $/ \mathrm{kg}$ diet recorded better feed conversion (2.2) as compared to the control group (2.4). Fisinin et al. (2011) reported that adding of silymarin decreased feed consumption and enhanced feed conversion of broiler chicken. 
Feed consumption during 8-16 and 4-16 weeks of age were significantly $(\mathrm{P}<0.05)$ influenced by interaction between stocking density and silymarin level (Table 3). It is clear that stocking density 12 birds $/ \mathrm{m}^{2}$ and 250 mg silymarin/Kg diet treatment recorded the best (4.37) feed conversion value as compared with the other treatments.

Mortality rate of chickens housed at $14 \mathrm{bird} / \mathrm{m}^{2}$ were significantly higher than those of birds housed at 10 bird $/ \mathrm{m}^{2}$ (Table 3 ). Increased mortality can be explained by decrease of animal welfare, such as bad air and litter quality, poor immune response, and poor feed intake. These results agreed with those obtained by Imeada (2000) who indicated that total mortality rate of broiler chickens housed at $18 \mathrm{bird} / \mathrm{m}^{2}$ were significantly higher than those of birds housed at 12 and $15 \mathrm{bird} / \mathrm{m}^{2}$. Tollba and El-Nagar (2008) found that increasing stocking density ( 8 to 12 birds $/ \mathrm{m}^{2}$ ) of Dandarawy chicks at $20 \mathrm{wks}$ of age had significantly $(\mathrm{P}<0.05)$ increased on mortality rate. Conversely, mortality rate decreased with silymarin supplementation levels (250 or $500 \mathrm{mg} /$ $\mathrm{Kg}$ diet) compared to the control diet (Table 3 ). These results are in agreement with those of Fisinin et al. (2011) who reported the absence of mortality in broiler chicken fed the liposomal nanoform of silymarin, so the livestock preservation in this group exceeded that in control by $2.86 \%$.

Total mortality rate of chickens were not significantly effected by interaction between stocking density and dietary silymarin level (Table 3). It could be noticed that stocking density of 14 birds $/ \mathrm{m}^{2}$ without silymarin supplementation recorded the highest mortality rate (19.05\%). Whereas, mortality rate decreased with silymarin supplementation levels at different stocking densities of these study. The lowest of mortality rate was recorded by stocking density of 12 birds $/ \mathrm{m}^{2}$ and $500 \mathrm{mg}$ silymarin/Kg diet (5.56\%).

\section{Carcass traits}

Averages of carcass yields in male chicks as affected by stocking density and dietary supplementation with silymarin and their interactions are presented in Table 4. Carcass, dressing, breast and thigh percentage relative to pre-slaughter were significantly $(\mathrm{P}<0.05)$ decreased while abdominal fat $\%$ was increased $(\mathrm{P}<0.05)$ with increasing stocking density $\left(12\right.$ or 14 birds $\left./ \mathrm{m}^{2}\right)$. These results are coincided with the findings of Dozier et al. (2005) who indicated that weight of carcass, breast and thigh decreased in a linear manner as stocking density increased. Increasing stocking density from 10 to 13 birds $/ \mathrm{m}^{2}$ has been shown to reduce breast fillet yield relative to $\mathrm{BW}$ but breast tender and total white meat yields were not affected by stocking density (Bilgili and Hess, 1995). Also, Hassanein (2011) found that high stocking density (9 birds $\left./ 0.485 \mathrm{~m}^{2}\right)$ had significantly $(\mathrm{P}<0.05)$ decreased carcass weight, breast weight and thigh weight at 6 weeks of age. On the contrary, carcass, dressing, 
breast $\%$ and thigh percentages relative to pre-slaughter were significantly $(\mathrm{P}<0.05)$ increased while abdominal fat $\%$ was significantly $(\mathrm{P}<0.05)$ decreased with dietary silymarin supplementation. Similarly, Zahid and Durrani (2007) reported that broilers fed different levels of milk thistle (silymarin) had significantly higher breast and thigh weights at the level of $15 \mathrm{~g} / \mathrm{Kg}$ feed. Chand et al. (2011) found that milk thistle level at $15 \mathrm{~g} / \mathrm{Kg}$ feed showed an increase of $5.96 \%$ in dressing percentage as compared with the control.

Interaction between stocking density and dietary silymarin level had no significantly effect on all carcass yields of cocks except for breast $\%$ at the end of experimental period. The best value of breast $\%$ was recorded by stocking density of 10 birds $/ \mathrm{m}^{2}$ and $250 \mathrm{mg}$ silymarin/Kg diet $(17.41 \%)$ followed by 10 birds $/ \mathrm{m}^{2}$ and $500 \mathrm{mg}$ silymarin/Kg diet (17.2\%).

\section{Tibia measurements and mineral contents}

The effect of using different stocking density and dietary silymarin level on tibia measurements and its mineral contents are given in Table 5. Data obtained indicated that tibia weight, tibia length, tibia calcium\% and tibia phosphorous\% (of ash) were significantly $(\mathrm{P} \leq 0.05)$ higher for male chicks kept at 10 birds $/ \mathrm{m}^{2}$, followed by those stocked at $12 \mathrm{birds} / \mathrm{m}^{2}$ then male chicks stocked at $14 \mathrm{birds} / \mathrm{m}^{2}$. The present results are coincided with the findings reported by Kestin et al., (1994) they found that high stocking density rates lead to reduce growth rate and increased incidence of diseases especially leg problems and various types of dermatitis. Martrenchar et al.,( 1997 \& 2000) reported that high stocking density have been shown to induce poor leg condition ,a decrease in locomotion behavior, condition, frequent disturbances in growth rate and a high incidence of dermatitis attributable to deteriorating litter condition. Kouichi et al., (2007) found that the bone mineral density at the proximal epiphysis in the male tibia stoppe increasing at $40^{\text {th }}$ days of age, whereas that in the female tibia continued to increase until 100 days of age. Also, Abdel-Azeem, (2010) indicated that tibia weight, tibia length, tibia width, tibia ash, tibia calcium and tibia phosphorous (\% of ash) of quail were significantly $(\mathrm{P} \leq 0.05)$ higher for quails kept at $77 \mathrm{birds} / \mathrm{m}^{2}$, followed by quails stocked at $100 \mathrm{birds} / \mathrm{m}^{2}$ then quails stocked at $143 \mathrm{birds} / \mathrm{m}^{2}$. Whoever, tibia measurements and mineral contents were not significantly affected by silymarin level supplementation or with interaction between stocking density and silymarin level.

\section{Breast and thigh chemical composition}

Results of chemical composition of breast and thigh of cocks as affected by stocking density and dietary supplementation with silymarin are illustrated in Table 6 . The analysis of variance indicated that there were no 
significant differences in chemical composition of breast and thigh of cocks due to stocking density effect. These results are in agreement with the results obtained by Abdel-Azeem (2010) who indicated that there were insignificant differences in moisture, dry matter, crude protein, ether extract, ash and nitrogen free extract (NFE) percentage of breast, thigh of quails at different stocking densities $\left(77,100\right.$ and143bird $\left./ \mathrm{m}^{2}\right)$. On the contrary, crude protein percentages of breast was significantly $(\mathrm{P}<0.05)$ increased while, ether extract percentage of breast and thigh were significantly $(\mathrm{P}<0.05)$ decreased with 205 and $500 \mathrm{mg}$ silymarin/Kg diet as compared with the control group. These results agreed with those of Schiavone et al., (2007) who reported that $40 \mathrm{ppm}$ and $80 \mathrm{ppm}$ of a sylimarin supplementation reduced lipid content of both breast and thigh and increased muscles resistance to oxidative stress. However, chemical composition of breast and thigh of cocks were not significantly affected by interaction between stocking density and silymarin supplementation.

\section{Blood hematological parameters}

Averages of blood hematological parameters in male chicks as affected by stocking density and dietary supplementation with silymarin are given in Table 7. Erythrocytes cells, leucocytes cells, heterophils $(\mathrm{H})$ and $\mathrm{H} / \mathrm{L}$ ratio were significantly $(\mathrm{P}<0.05)$ increased while, lymphocytes $(\mathrm{L})$ were insignificantly decreased with increasing stocking density from 10 to 12 or 14 birds / m2. Social environment stress may be responsible for the increase of erythrocytes observed in birds housed in highest density. Shini (2003) reported that heterophils were raised while, lymphocytes decreased for hens kept in battery cages. The alterations in heterophils, lymphocytes cells or $\mathrm{H} / \mathrm{L}$ ratio suggested that hens of different stoking densities had a great effect on the stress response. Tollba et al. (2006) found that erythrocytes and leucocytes (Eosinophil, basophil and monocyte and heterophils) were increased with the highest stocking density (16 birds / $\mathrm{m} 2$ ). Also, they added that a significant raise in heterophils cells number, together with a corresponding significant reduction in lymphocyte cells number was observed. Also, Tollba and El-Nagar (2008) demonstrated that increasing stocking density recorded higher $(\mathrm{P}<0.05)$ values of erythrocytes and leucocytes as well as heterophils of layers blood, with a corresponding lower $(\mathrm{P}<0.05)$ values of lymphocytes cells number compared to normal density. Leucocytes cells and lymphocytes were significantly $(\mathrm{P}<0.05)$ decreased while, erythrocytes, heterophils and $\mathrm{H} / \mathrm{L}$ were not significantly affected by silymarin supplementation levels. Fisinin et al. (2011) reported that number of leukocytes of broiler chicks was lower with silymarin supplementation whereas, number of erythrocytes was greater than in the control. Blood hematological parameters in male chicks were not significantly 
affected by interaction between stocking density and silymarin supplementation.

Serum globulin value was significantly $(\mathrm{P}<0.05)$ decreased while, serum total protein, albumin, cholesterol, AST and ALT values were insignificantly affected by increasing stocking density from 10 to12 or 14 birds $/ \mathrm{m}^{2}$, Table 8 . The present results are in partial agreemrnt with the findings reported by El-sheikh and Nagwa (2006) they reported that the high stocking density $\left(10 \mathrm{bird} / \mathrm{m}^{2}\right)$ of broiler chicks led to significant $(\mathrm{P} \leq 0.05)$ decrease in the total protein, albumin, globulin and haemoglobine, while it led to increase GOT and values cholesterol during summer season. Whereas, El-Deek and AlHarthi, (2004) found that there were no significant impacts of stocking density $\left(10,14\right.$ or $\left.18 \mathrm{bird} / \mathrm{m}^{2}\right)$ on the plasma cholesterol, AST and ALT values. O* zbey and Esen (2007) reported that stocking density of rock partridges significantly $(\mathrm{P}<0.05)$ decreased blood total protein, whereas it had no significant effect on blood AST and ALT (P > 0.05) values. Sekeroglu et al. (2011) stated that stocking densiteis $\left(9,13\right.$ and 17 birds $\left.\mathrm{m}^{2}\right)$ had significantly $(\mathrm{P}<0.05)$ influence on total plasma protein content. Serum total protein and globulin values were significantly $(\mathrm{P}<0.05)$ increased, While, serum AST and ALT values were significantly $(\mathrm{P}<0.05)$ decreased and serum albumin and cholesterol values were not significantly affected with dietary silymarin supplementation. These biochemical shifts can be the result of enhanced protein synthesis in the liver induced by silymarin, as well as reduced rate of albumin destruction and converting it to other proteins, partially to globulin. Fisinin et al. (2011) demonstrated that total protein was increased by $9.4 \%$ while, cholesterol was decreased by $23.8 \%$ in group of broiler chicks fed the liposomal nanoform of silymarin than in the control group. Feeding the nanosomal form of the flavolignan silycristin supplement contributed to a decrease in enzymes activity of ALT and AST by 33.3 and $16.6 \%$, respectively which probably reflects hepatoprotective effects of silymarin (Lutsenko et al, 2008). Suchý et al. (2008) reported that feeding broiler on $1.0 \%$ of Silybum marianum seed cakes (contained $2.95 \%$ of silymarin) significantly $(\mathrm{P}<0.01)$ lowers cholesterol levels on the 43rd day and dietary $0.2 \%$ of Silybum marianum seed cakes significantly $(\mathrm{P}<0.05)$ lowers cholesterol levels on the 52rd day when compared with the control group. Also the ALT and AST activities were lower $(\mathrm{P}<0.01)$ in both experimental feeding levels on the 22nd day of the experiment.

Only, serum globulin was significant $(\mathrm{P}<0.05)$ influenced by interaction between stocking density and silymarin level.

\section{Economical efficiency:}

Results of economical efficiency of cocks as affected by stocking densities and dietary supplemented with silymarin are showed in Table 9. 
Increasing stocking density to 12 birds $/ \mathrm{m}^{2}$ gave the best net revenue and economical efficiency \% compared with that of 10 or 14 birds $/ \mathrm{m}^{2}$. The best net revenue and economical efficiency were recorded with cocks fed $250 \mathrm{mg}$ silymarin $/ \mathrm{Kg}$ diet and followed byvalues of cocks fed $500 \mathrm{mg}$ silymarin $/ \mathrm{Kg}$ diet as compared with the control group. Regarding the interaction effect, results in Table (9) demonstrated that the best economical efficiency value during the whole experimental period was obtained with 12 birds $/ \mathrm{m}^{2}$ and $250 \mathrm{mg}$ dietary silymarin level $/ \mathrm{Kg}$ diet. This may be due to the good performance of this treatment.

In conclusion, from the nutritional and physiological points of view it could be concluded that increasing stocking density to 12 birds $/ \mathrm{m}^{2}$ also, the use of 250 or $500 \mathrm{mg}$ silymarin $/ \mathrm{Kg}$ diet improved most productive performance and some physiological traits of Inshas cocks.

\section{REFERENCES}

Abdel-Azeem, F.A.A (2010). The influence of different stocking density and sex on productive performance and some physiological traits of Japanese quail. Egypt. Poultry. Sci., 30 (I): 203-227.

Al Homidan, A. and Robertson, J.F., (2007). The effect of stocking density and litter type on ammonia, dust, carbon dioxide concentrations and broiler performance. Egypt. Poultry. Sci., 27 (I): 37-51.

Arkhapchev, M.Yu.; Kashnikova, T.V.; Druz', E.A.; Luzhnov, N.D.; Lutsenko, S.V.; Arkhapchev Yu.P.; Fel'dman, N.B.; Lutsenko, E.V. and Bykov, V.A., (2009). Microscopic Study of the Liposomal Silycristin and Its Hepatoprotective Effects, Voprosy biologicheskoi, meditsinskoi i farmatsevticheskoi khimii, 4:21-24.

Association of Official Analytical Chemists, AOAC. (1994)., Official Methods of Analysis, $15^{\text {th }}$ Ed., published by the AOAC, Washington, DC. USA.

Bennett, D.D.; Higgins, S.E.; Moore, R.W.; Beltran, R.; Caldwell, D.J.; Byrd, J.A. and Hargis, B.M. (2003). Effects of lime on Salmonella enteritidis survival in vitro. Applied Polt. Res., 12: 65-68.

Bilgili, S.F. and Hess, J.B., (1995). Placement density influences broiler carcass grade and meat yields. J. Applied Poult. Res., 4: 384-389.

Chand, N.; Durrani., F. R.; Qureshi, M.S.; Muhammad, D. and Rehman, Z. (2011). Protective effects of milk thistle (silybum marianum) against aflatoxin B1 in broiler chicks. Asian Aust, J. Anim. Sci, 24:1011 - 1018 .

Doumas, B. (1971). Colorimetric determination of serum albumin. Clin.Chem.Acta., 31: 400-403. 
Dozier I., W.A., Thaxton, J.P.; Branton, S.L.; Morgan, G.W. and Miles, D.M. (2005). Stocking density effects on growth performance and processing yields of heavy broilers. Poultry Sci., 84: 1332-1338.

Duncan, D. B. (1955). The Multiple Range and Multiple F-Test. Biometrics, 11: 1-42.

Egorov, I. and Papazyan, T.,(2007) Modern Tendencies in Poultry Nutrition, Ptitsevodstvo, 8: 9-11.

El-Deek,A .A. and Al-Harthi, M. A.(2004). Responses of modern broiler chicks to stocking density, green tea, commercial multi enzymes and their interaction on productive performance, carcass characteristics, liver composition and plasma constituents. International Journal of Poultry Sci., 83 (10): 635- 645

El-sheikh, T. M and Nagwa S. Ahmad(2006). An attempt to alleviate heat stress of broiler chicks during summer season through stocking density, dietary organic selenium (sel-plex) and vitamin e-selemium. Egypt. Poultry Sci., 26 (IV): 1587-1611.

Estevez, I., (2007). Density allowances for broilers: Where to set the limits. Poultry Sci., 86: 1265-1272.

Feddes, J.J.; Emmanuel, E.J. and Zuidhoft, M.J. (2002).Broiler performance, body weight variance, feed and water intake and carcass quality at different stocking densities. Poultry Sci., 81:774-779.

Fisinin V.I. and Tardat'yan, A.G., (2003). Current Strategies of Safe Poultry Feeding, Ptitsa i ptitseproducty, 5: 21-26.

Fisinin, V.I.; Egorov, I.A.; Andrianova, E.N.; Morina, E.A.; Fel'dman, N.B., Lutsenko, E.V. and Lutsenko', S.V. (2011). Influence of liposomal nanoform of flavolignan complex from silybum marianum L. (silymarin) on main zootechnical and physiological parameters in broiler-chicken. Сельскохозяйственная биология, 4: 30-35.

Gowda, S. K. and Sastry, V. R. B. (2000). Neem (Azadirachta indica) seed cake in animal feeding-scope and limitation - Review. Asian-Aust. J. Animal Sci., 13(5):720-728.

Hassanein , H.H.M. (2011). Growth performance and carcass yield of broilers as affected by stocking density and enzymatic growth promoters. Asian Journal of Poultry Science, 5: 94-101.

Hawkey, C.M. and Dennett, T.B. (1989). Color Atlas Of Comparative Veterinary Hematology. Iowa State University Press, Ames.

Imaeda, N. (2000). Influence of stocking density and rearing season on incidence of sudden death syndrome in broiler chickens .Poult.Sci.,79: 201-404. 
Kestin,S.C.; Adams, S.J.M. and Gregory, N.G. (1994). Leg weakness in broiler chickens, a review of studies using gait scoring. Proceeding 9th European Poultry Conference, 203-205.

Kouichi, N.; Susumu, M.; Takao, T.; Eishi, A. T. and Seiji, K. (2007). Changes in the outer shape, inner structure and bone mineral density of the tibia of growing Japanese quail, (Coturnix japonica). J. of Poult.Sci.,44: 426-432.

Kurkin V.A., (2003). Milk thistle Silybium marianum as a source of medicinal substances, Khimiko-farmatsevticheskii zhurnal, 4: 27-41.

Leone, E.H.; Christman, M.C.; Douglass, L. and Estevez, I. (2010). Separating the impact of group size, density and enclosure size on broiler movement and space use at a decreasing perimeter to area ratio. Behav. Processes, 83: 16-22.

Lutsenko, E.V.; Arkhapchev, M.Yu.; Druz', E.A.; Kashnikova, T.V.; Arkhapchev, Yu.P.; Fel'dman, N.B.; Lutsenko, S.V. and Bykov V.A., (2008). Synthesis and Investigation of Antihepatotoxic Activity of Nanosomal Form of the Flavolignan Silycristin, Voprosy biologicheskoi, meditsinskoi ifarmatsevticheskoi khimii,6:19-23.

Martrenchar, A.; Huonnic, D.; Cotte, J.P.; Boilletot, E and Morisse, J.P. (2000). Influunce of stocking density, artificial dusk and group size on the perching behaviour of broilers. Brit. Poultry Sci., 41:125-130.

Martrenchar, A.; Morisse, J.P.; Huonnic, D. and Cotte, J.P. (1997). The influence of stocking density on some behavioral, physiological and reproductive traits of broiler. Vet.Res.,28:473-480.

NRC. (1994). National Research Council .Nutrient Requirements of Poultry. $9^{\text {th }}$ Ed, National Academic of Science. Washington, DC. USA.

O“ Zbey, O. and Esen, F. (2007). The Effects of Breeding Systems and Stocking Density on Some Blood Parameters of Rock Partridges (Alectoris graeca). Poultry Science, 86:420-422.

Puron, D.; Santamaria, R.; Segaura, J.C. and Alamilla, J.L. (1995). Broiler performance at different stocking densities. Appl.Poult.Res.,4:55-60.

Retiman, S. and Frankel, S. (1957). Colorimeteric method for determination of serum transaminase activity. American J. of Clinical Pathology., 28: 65-68.

Ritz, C.W.; Fairchild, B.D. and Lacy, M.P. (2005). Litter quality and broiler performance. Cooperative Extension Service, The University of Georgia College of Agricultural and Environmental Sciences. Bulletin, 1267.

SAS Institute, (2003). SAS User's Guide: Statistics. Version 8.2, SAS Institute Inc., Cary, NC. 
Schiavone, A.; Righi, F.; Quarantelli, A.; Bruni, R.; Serventi, P. and Fusari, A. (2007). Use of Silybum marianum fruit extract in broiler chicken nutrition: influence on performance and meat quality. $J$. Animal Physiol., 91:256-262.

Sekeroglu, A.; Sarica, M; Gulay, M.T. S. and Duman, M. (2011). Effect of stocking density on chick performance, internal organ weights and blood parameters in broilers. Journal of Animal and Veterinary Advances, 10 (2): 246-250.

Shanawany, M.M., (1988). Broiler performance under high stocking densities. Br. Poult. Sci., 29: 43-52.

Shini, S. (2003). Physiological responses of laying hens to the alternative housing systems. International Journal of Poult. Sci., 2(5):357-360.

Skomorucha, I.; Muchacka, R.; Sosnowka-Czajka, E. and Herbul, E. (2009). Response of broiler chickens from three genetic groups to different stocking densities. Ann. Anim. Sci., 9: 175-184.

Suchý, Jr. P.; Straková, E.; Kummer, V.; Herzig, I.; Písaříková, V.; Blechová, R. and J. Mašková (2008). Hepatoprotective effects of milk thistle (silybum marianum) seed cakes during the chicken broiler fattening. Acta Vet. Brno., 77: 31-38.

Tedesco, D.; Domeneghini, C.; Sciannimanico, D.; Tameni, M.; Steidler, S. and Galletti., S. (2004). Efficacy of silymarinphospholipid complex in reducing the toxicity of aflatoxin B1 in broiler chicks. $J$. Poult. Sci., 83(11):1839-1843.

Tollba A.A. H. and El-Nagar, A. H. I. (2008). Increasing stocking density of Egyptian laying hens by using: 3 - Increasing protein level Betaine supplementation. Egypt. Poultry Sci., 28 (III): 745-766.

Tollba, A.A.H.; Rizkalla, H. E. and Abd El-Samad, M. H. (2006). Effects of stocking density on productive and physiological performance of Egyptian laying chickens. Egypt. Poultry Sci., 26: 335-346.

Turkyilmaz, M.K. (2008). The effect of stocking density on stress reaction in broiler chickens during summer. Turk. J. Vet. Anim. Sci., 32: 31-36.

Watson, M., (1960). A method for determination of cholesterol. Clin. Bioch. 58 (4): 379-382.

Wilasrusmee, C.; Kittur, S.; Shah, G.; Siddiqui, J.; Bruch, D.; Wilasrusmee, S. and Kittur, D.S., (2002).Immunostimulatory effect of Silybum marianum (Milk Thistle) Extract, Med. Sci. Monit.,8: 439-443.

Witt, L. and Trendelenburg, C. (1982). A method for rapid determination of total protein of serum, J. P. Clin., Biochem., 20: 235. 
Zahid, R. and Durrani, F. R. (2007). Biochemical, hematological, immunological and growth promotant role of feed added Milk Thistle (Silybum marianum) in broiler chicks. M.Sc. (Hons) Thesis submitted to NWFP Agric. Univ., Peshawar, Pakistan.

Zuowei, S.; Yan, L.; Yuan, L.; Jiao, H.; Song, Z.; Guo. Y and Lin, H. (2011). Stocking density affects the growth performance of broilers in a sex-dependent fashion. Poultry Sci., 90 (7): 1406-1415.

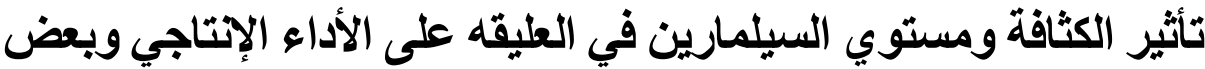
الصفات الفسيولوجية لذيوي الدو انثاص على المحلية

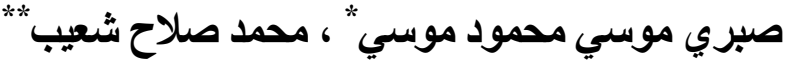

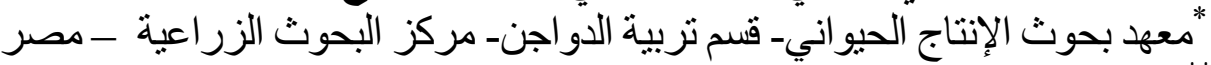

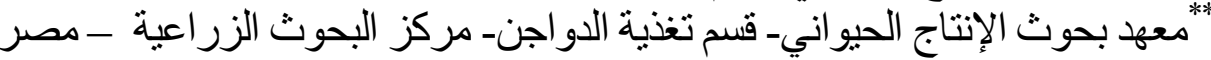

أجريت هذه الدر اسة بهدف دراسة تأثير الكثافة ومستوى السيليمارين في النظام

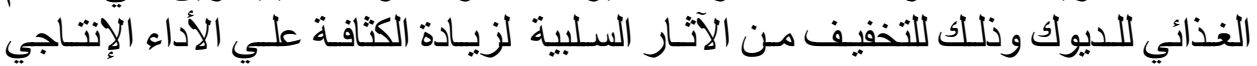

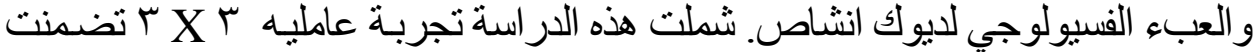

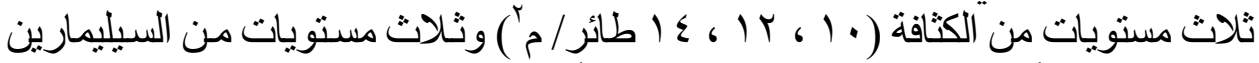

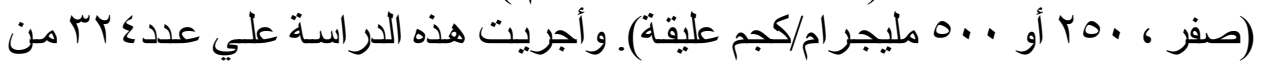

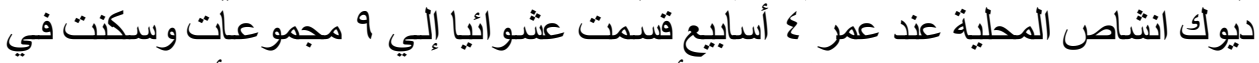

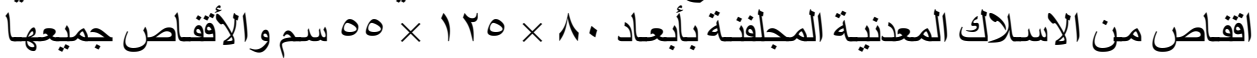

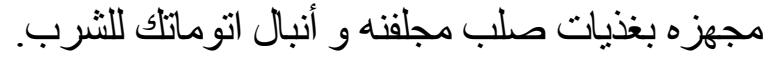

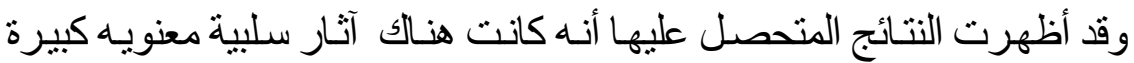
(P<0.05) (بلى وزن الجسم الحي، و الزيادة الوزنية للجسم، و الغذاء المستهلك (باستثناء

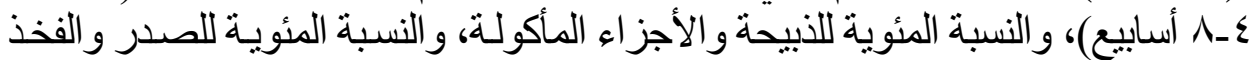

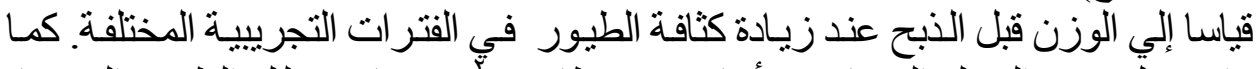

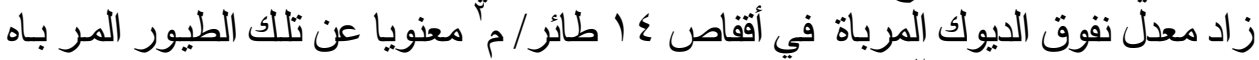

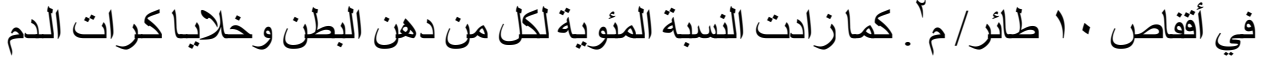

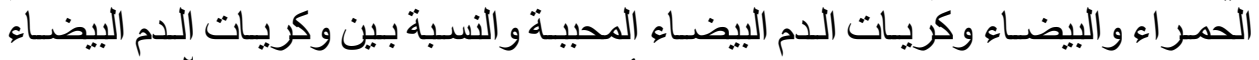

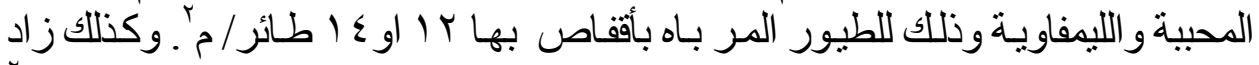

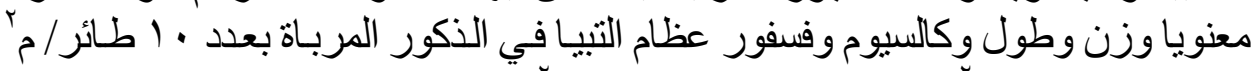

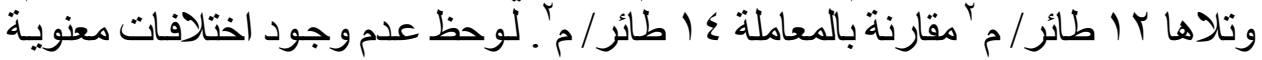

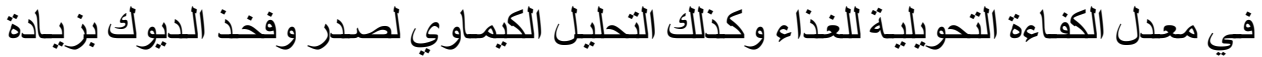


تحسن وزن الجسم و الزيـادة الوزنيـة (غالبـا) معنويـا (P>0.05) مـع مستويات

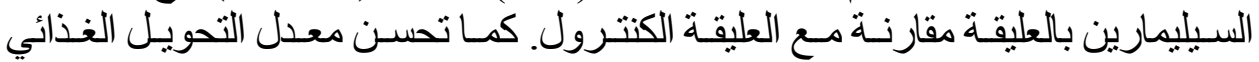

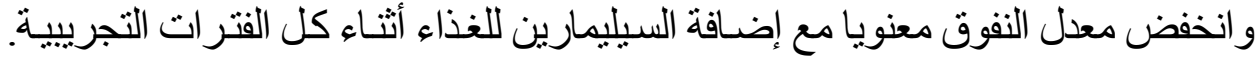

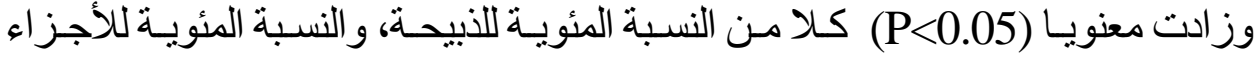

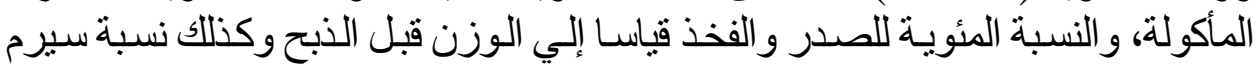

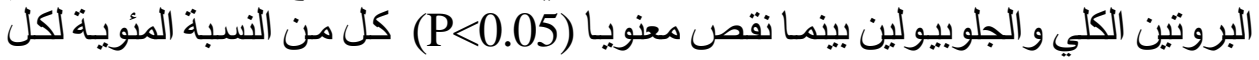

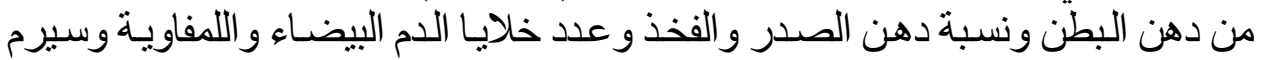

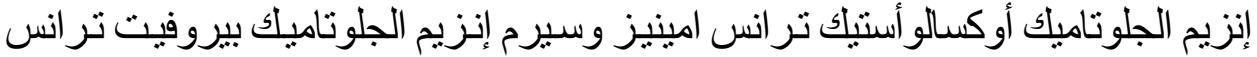

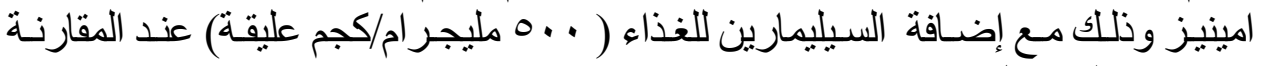
بمجمو عه الكنترول.

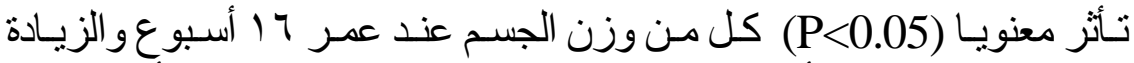

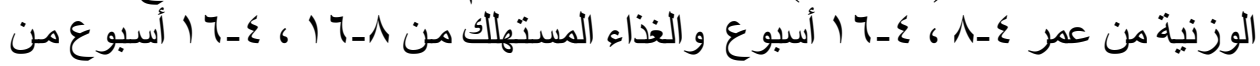

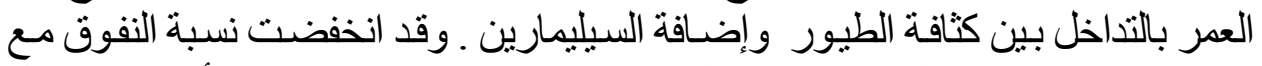

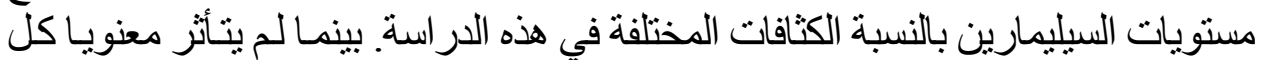

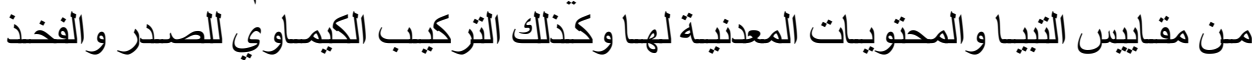
للايوك نتيجة التداخل بين الكثافة و السيليمارين.

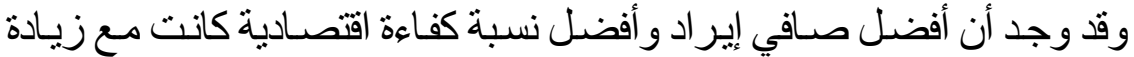

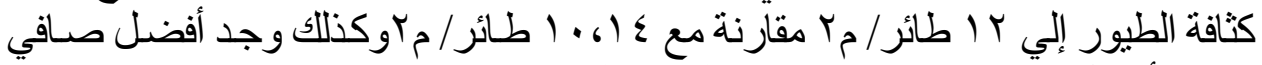

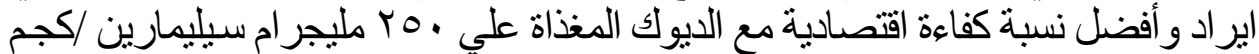

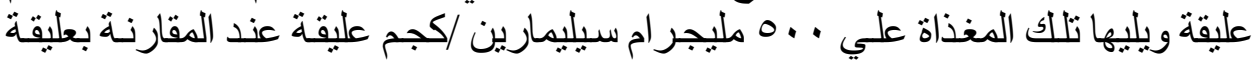

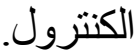

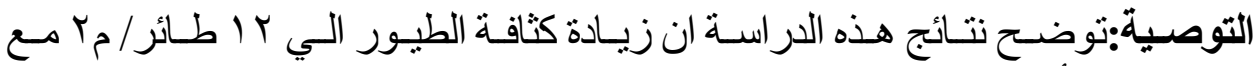

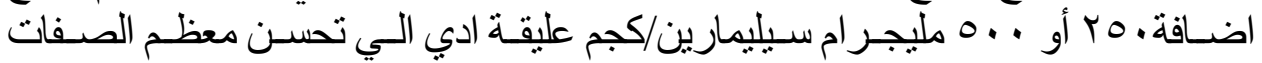
الإنتاجية والفسيولوجية لديوك انشئه أنشاص المحلى. 